\title{
Hvad er der galt med Frankrig?
}

Af Jørn Boisen

Frankrig er Europas syge mand, sagde Polens udenrigsminister Jacek Czaputowicz kort før julen 2018. Frankrig trækker Europa ned, sagde han og pegede på terrorangrebet i Strasbourg den 11. december, de gule vestes demonstrationer, franskmændenes kroniske raseri og præsident Emmanuel Macrons svage opbakning. Macron burde rydde op i eget hus og ikke belære Polen om, hvordan en retsstat fungerer, mente den polske udenrigsminister.

Det er uden tvivl enklere for den polske regering at holde styr på et land, hvor loyale partistøtter er blevet placeret på alle samfundets nøgleposter, og hvor regeringen er ved at have fuld kontrol over domstole og medier, men iagttagelsen er ikke forkert; der er noget galt i Frankrig. Set fra Nordeuropa er det både fascinerende og foruroligende at betragte Frankrig. Det er åbenlyst for enhver, at der er noget, der ikke fungerer, som det skal. Det interessante spørgsmål er imidlertid, hvilken diagnose der skal stilles. Hvis Frankrig er Europas syge mand, hvad fejler han så? Er det kroppen, den er gal med? Eller er det snarere hovedet?

\section{Rigets tilstand}

Man får ikke noget entydigt svar, når man ser på de økonomiske nøgletal, for Frankrig er ikke i værre forfatning end mange andre EU-lande.

Forholdet mellem den offentlige og den private sektor er tæt på det forhold, som man finder i Danmark. Produktiviteten per arbejdstime er ifølge Eurostat på niveau med den danske, dvs. lidt højere end i Tyskland og langt højere end EU-gennemsnittet. Arbejdsstyrken er generelt velkvalificeret med 37 pct., der har en længere

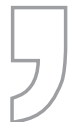

Hvis Frankrig er Europas syge mand, hvad fejler han så? Er det kroppen, den er gal med? Eller er det snarere hovedet? 


\section{Det eneste entydigt negative, der adskiller Frankrig fra de europæiske} partnere, er arbejds|øshedstallene. I 30 år har arbejdsløsheden ikke været nede under 7,5 pct. i Frankrig, og i de sidste 10 àr har den ligget stabilt omkring de 10 pct.

videregående uddannelse mod 28 pct. i Tyskland. Prisen per arbejdstime i industrien er lidt højere end i Tyskland: 36,7 euro mod 34,7 euro (2016tal). Der er færre fattige (defineret som mennesker, der lever for under 60 pct. af medianindkomsten) end i Tyskland: 14,3 pct. i Frankrig mod 16,7 pct. i Tyskland. Anlægger man et grønt perspektiv, udleder en franskmand ifølge Verdensbankens tal stort set kun halvt så meget $\mathrm{CO}_{2}$ (5,05 ton) som en tysker 9,22. Frankrig går op i sin strategiske uafhængighed, og derfor har man ikke villet opgive atomkraften, der jo ikke er afhængig af, hvad der sker i Mellemøsten og Rusland, og som er $\mathrm{CO}_{2}$-neutral.

Til gengæld er væksten i Frankrig ikke på niveau med de europæiske partneres: 1,2 pct. af BNP i 2016, 2,2 pct. i 2017 og 1,7 pct. i 2018. I den samme periode har Tyskland ligget stabilt på 2,2 pct. hvert år, og Danmark på henholdsvis 2,0, 2,2 og 1,9 pct. Der er altså lidt svagere vækst i Frankrig, uden at tallene dog er dramatisk dårlige; 1,5 pct. vækst tillader at opretholde status quo. 1,7 pct. gør det muligt at skabe nye arbejdspladser.

Det eneste entydigt negative, der adskiller Frankrig fra de europæiske partnere, er arbejdsløshedstallene. I 30 år har arbejdsløsheden ikke været nede under 7,5 pct. i Frankrig, og i de sidste 10 år har den ligget stabilt omkring de 10 pct. I dag er den på 9,3 pct. For unge er arbejdsløsheden mellem 20 og 25 pct. For ufaglærte unge er den oppe på 50 pct. Det er et problem, og det er kronisk.

Disse tal giver et meget godt billede af et af det franske samfunds store udfordringer. Det franske arbejdsmarked er som et asymmetrisk timeglas: De øverste $3 / 4$ af arbejdsmarkedet er veluddannede, produktive og vellønnede. Den nederste fjerdedel består af mennesker med kort eller uden uddannelse, de kommer fra ikke-boglige hjem, de bor på steder, hvor økonomien er gået i stå, og hvor der er dårlig infrastruktur, og de er ikke sjældent indvandrere eller børn af indvandrere. Den sociale arv er tung, og den sociale mobilitet er begrænset. Frankrig har altså et socialt problem, der hænger sammen med et geografisk problem, der hænger sammen med et etnisk problem. Det er på mange måder en eksplosiv cocktail.

\section{Frihed, lighed, mismod}

Hvis man kan se bort fra den strukturelle arbejdsløshed, er Frankrig et af de mest velstående og velfungerende lande i Europa. Landet er på alle punkter i langt bedre forfatning end de reelt kriseramte middelhavslande, Grækenland, Italien, Spanien, Portugal, som man lidt hurtigt slår det $\mathrm{i}$ hartkorn med.

Det er altså ikke kroppen, den er gal med, hvis vi skal blive i den polske 
De seneste 30 år har fransk politik udviklet sig til et sovjetisk supermarked, et foretagende der er karakteriseret ved, at det ikke har det, som man efterspørger, og at man ikke vil have det, som det har på hylderne.

udenrigsministers sygdomsmetafor; det er hovedet.

Man ved, at Danmark i mange år har ligget i toppen af FN's lykkeindeks. Selvom danskerne i $2018 \mathrm{blev}$ overhalet af både finner og nordmænd, er vi stadig blandt de lykkeligste i verden. Franskmændene er blandt de mindst lykkelige.

Siden 2009 har CEVIPOF, der er en forskningsenhed på Sciences Po i Paris, målt franskmændenes sindstilstand og deres tillid til samfundsinstitutionerne. Den sidste rapport udkom januar 2019, og det er træthed, mistillid og mismod, der dominerer billedet.

Selvom der er udslag på de forkerte steder, er situationen mere kompleks. Hvad angår deres egen situation, er franskmændene nemlig ikke specielt negative. Fire ud af fem mener, at de har det godt. Næsten hver anden (43 pct.) kan lægge lidt penge til side, når måneden er omme. Når franskmændene kun skal forholde sig til deres eget konkrete liv, har de en grad af tilfredshed, der afspejler de makroøkonomiske realiteter.

Når det derimod kommer til kollektivet, fællesskabet, nationen, er der ingen grænser for pessimismen. Der er ingen tro på fællesskabets fremtid. Kun 16 pct. af de adspurgte franskmænd synes, at det går godt i landet. I Tyskland er det tilsvarende tal 38 pct. I Storbritannien, der sociologisk er det land, der ligner Frankrig mest, er det 32 pct., altså dobbelt så mange, der tror på fællesskabet!

Individuelt har de fleste franskmænd det altså godt, men kollektivt har de det skidt. Denne manglende tro på kollektivet og på fremtiden er bagtæppet for de politiske begivenheder, der udspiller sig i Frankrig.

\section{Det sovjetiske supermarked}

Der er to grunde til, at den unge og politisk uprøvede Emmanuel Macron vandt det franske præsidentvalg i 2017. For det første er han et uomtvisteligt politisk talent, for det andet var han ny. Macron vandt dybest set, fordi det gamle partisystem brød sammen.

De seneste 30 år har fransk politik udviklet sig til et sovjetisk supermarked, et foretagende der er karakteriseret ved, at det ikke har det, som man efterspørger, og at man ikke vil have det, som det har på hylderne. Utilfredsheden er gennemgribende og gælder både institutionerne, det politiske system og de siddende magthavere.

Mange franskmænd har simpelthen opgivet politik. De deltager stadig mindre i formelt politisk arbejde, og de går mindre op i det. En undersøgelse fra februar 2017 - lige inden præsidentvalget, det eneste valg, der virkelig tæller i Frankrig - gav et bekymrende resultat. Kun 18 pct. af vælgerne havde en positiv holdning til politik, eller var bare interesserede i politik.

Det har konsekvenser for valgdeltagelsen. Præsidentvalget i 2017 var høj- 
dramatisk, og man nåede en stemmeprocent på 77 i første runde. Da man nåede hen til parlamentsvalgets anden runde godt en måned senere, var stemmeprocenten 43,4 . I aldersgruppen mellem 18 og 24 var stemmeprocenten helt nede på 26. I aldersgruppen 25 til 34 var den 30 pct. Det er ekstremt bekymrende, for det undergraver valghandlingens legitimitet, når så mange lader være med at stemme.

Der er stadig generel opbakning til demokratiet som styreform (89 pct.), men 63 pct. mener, at demokratiet i dets nuværende form er dysfunktionelt: det er dårligt til at tage beslutninger (68 pct.); det kan ikke opretholde lov og orden (44 pct.); og det ville være bedre at erstatte det repræsentative demokrati med et mere direkte demokrati (59 pct.) - et af populismens bærende temaer.

Utilfredsheden ytrer sig især i en nådesløs vurdering af de valgte politikere. De franske vælgere har ikke tillid til, at de folkevalgte arbejder i almenvellets interesse men mistænker dem for at pleje særinteresser.

Situationen er ikke ny. I 2005 nåede præsident Jacques Chiracs popularitet et lavpunkt. Kun hver fjerde vælger havde tillid til ham. Det var det dårligste resultat, der var blevet målt, siden man var begyndt at måle i 1979. Ti år senere kunne Chirac godte sig over, at hans efterfølger, Nicolas Sarkozy, gjorde det endnu dårligere; Kun hver femte vælger havde i 2011 tillid til den siddende præsident. Fem år senere var de så Sarkozys tur til at glæde sig over, at efterfølgeren, François Hollande, var blevet så upopulær, at han på forhånd opgav at genopstille til præsidentvalget. Den socialistiske reservekandidat, Benoît Hamon, fik blot seks pct. af stemmerne. Ved det efterfølgende parlamentsvalg mistede det regerende socialistparti ikke blot det absolutte flertal, men hele 90 pct. af mandaterne, og det gamle regeringsbærende socialistparti eksisterer efterhånden kun som en eftertanke.

Utilfredsheden kommer normalt oppositionen til gode. Fransk politik er et uperfekt topartisystem. Valgsystemet, flertalsvalg ad to omgange, gør, at det altid ender som et opgør mellem to blokke, men det er uperfekt, fordi der er en halv snes partier, der kanaliseres ind i denne tvekamp. $\mathrm{Da}$ franskmændene hurtigt bliver trætte af den til enhver tid siddende regering, skifter magten mellem højre og venstre med en vinduesviskers regelmæssighed. En regering overlever aldrig et valg.

Før valget i 2017 var der lagt op til, at det var de borgerliges tur. Præsident Hollande og hans regering var så upopulær, at det i princippet var et valg, der ikke kunne tabes. Men kun tre måneder før præsidentvalgets første runde blev det afsløret, at den borgerlige spidskandidat, François Fillon, havde ladet staten aflønne sin hustru rundhåndet, uden at hun af den grund havde udført nogen jobfunktion. Det blev den begivenhed, der 'disruptede' fransk politik.

\section{Hvem er bange for Marine le Pen?}

Det havde længe ligget i luften, hvad alternativet var. Det ekstreme højre, Front National, har i 2010'erne under 
ledelse af Marine le Pen konsolideret sig som den mest stabile politiske formation i Frankrig. Siden 2011 ligger tilslutningen fast på omkring 25 pct. Det blev tidligere betragtet som lidt af en naturlov, at der var et glasloft på omkring 20 pct. over tilslutningen til ekstreme partier, men Marine le Pen har arbejdet hårdt på at normalisere partiet.

Hun har gjort op med den slet skjulte antisemitisme, som faderen og partistifteren Jean-Marie le Pen luftede fra tid til anden. Hun har også lagt afstand til racisme. Det betyder ikke, at hun var venligere stemt over for indvandrere, men nu udtrykker hun sin fjendtlighed med udgangspunkt i en venstrefløjsideologi, nemlig kul-

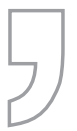

Fra 2015 til valget i 2017 var det ikke blot Front national, der satte dagsordenen; Front national var dagsordenen. Uanset hvad det blev gjort eller ikke gjort, var spørgsmålet: Hvordan kommer det her til at gavne Front national?

turalismen. Kulturalismen er forestillingen om, at individer determineres af deres kultur, at en kultur er en lukket, organisk helhed, der ikke kan blande sig med andre. Individet kan ikke forlade sin kultur, men kun realisere sig inden for den. Kulturalisme hævder også, at kulturer har krav på særlige rettigheder og beskyttelse. I Marine le Pens optik er det fransk kultur, der har behov for beskyttelse. Med det kulturalistiske lingo kan Marine le Pen være klar i mælet over for indvandringen, uden at hun af den grund kan beskyldes for at være racist.
Marine le Pen har også overtaget en anden venstrefløjsdagsorden, nemlig forsvaret af samfundets udsatte, mennesker med korte eller dårlige uddannelser, der enten har mistet deres job eller er bange for at gøre det. De regeringsbærende partier, republikanerne og socialisterne, er for længst steget på globaliseringens tog. Marine le Pen har samlet de dagsordener, som de efterlod, op: den nationale og den sociale. Det har gjort hende til en tilsyneladende ustoppelig kraft i fransk politik. Fra 2015 til valget i 2017 var det ikke blot Front National, der satte dagsordenen; Front National var dagsordenen. Uanset hvad det blev gjort eller ikke gjort, var spørgsmålet: Hvordan kommer det her til at gavne Front National?

I franske medier bliver Front Nationals mutation under Marine le Pen kaldt 'dédiabolisation' afdiabolisering. Det gælder om, at gøre partiet stuerent. Vælgertilslutningen til Front National er et af de mest studerede emner i fransk politik. Man kan først konstatere nogle forventede sammenfald: Stemmeprocenten på Front National er ligefrem proportional med arbejdsløshedsprocenten. Den franske demograf og historiker Hervé le Bras udtrykte det endnu mere sigende: Stemmeprocenten på Front National er ligefrem proportional med afstanden til nærmeste jernbanestation. Sammenhængen er klar. Marine le Pen står stærkt i de områder, som globaliseringen er kørt udenom, hvor staten trækker sig 
tilbage, og hvor infrastrukturen er under afvikling.

Det er stadig et spørgsmål i hvor høj grad stemmerne på Marine le Pen er ren protest, og i hvor høj grad de udtrykker egentlig tilslutning til hendes idéer. Jean-Marie le Pen fik ofte stemmer fra vælgere, der ikke nødvendigvis var enige i hans politiske dagsorden, men som var trætte af de andre partier og ville lægge pres på dem. Det har tilsyneladende også ændret sig. Den tredjedel af vælgerne, der stemte på hende ved præsidentvalgets anden runde i 2017, er tilsyneladende også enige i hendes idéer.

Front Nationals stærke stilling har vendt logikken i det franske valgsystem på hovedet. Det er et flertalsvalg $i$ to runder. I første runde luges der ud i de mange kandidater, og i anden runde samles de mange tendenser i en tvekamp, der normalt står mellem højre og venstre. Valgkampsstrategien er hægtet op på den proces. I kampagnen inden første runde gælder det om at mobilisere kernevælgerne, og synspunkterne har ofte en del kant. I anden runde gælder det om at vinde andre vælgere over, og der er synspunkterne mere midtsøgende og konsensuelle. Denne mekanik forstyrres, når et ekstremt parti som Front National er det største. Front National vil nemlig vinde første runde, men partiet er stadig så ekstremt, at det i langt de fleste tilfælde vil tabe anden runde. 51 pct. af de franske vælgere er stadig bange for Marine le Pen. Det betyder, at første runde i realiteten kommer til at fungere som anden runde, idet den, der kommer videre sammen med Front National, vil vinde valget. Præsidentvalget er et godt eksempel på mekanismen, i første runde fik Macron 24 pct. og le Pen 21 pct., knap en million stemmer adskilte dem. I anden runde fik Macron 66 pct. og le Pen 34 pct., hvilket svarer til en forskel på 10 millioner stemmer mellem de to kandidater.

Men hvordan skal man så føre valgkamp? Skal man satse på kernevælgerne, eller skal man satse bredt? Indsatsen er høj, for hvis man ikke lægger den rigtige strategi, er der risiko for, at det ikke bliver et, men to ekstreme partier, der går videre. Venstrepopulisten Jean-Luc Mélenchon fik således knap 20 pct. af stemmerne i første runde i 2017 med kun 1,6 mio. stemmer færre end Macron. Der var udtalt frygt i fransk erhvervsliv og i det franske embedsværk for, at anden runde ville byde på en duel mellem le Pen og Mélenchon, altså mellem to populister, hvis program var at trække Frankrig ud af euroen og dermed sandsynligvis udløse en gældskrise, der ville får den græske til at ligne en solstrålehistorie.

\section{Mistillidssamfundet}

Det er vigtigt at holde fast $i$, at når man betragter Frankrig fra makroøkonomiens olympiske perspektiv, går det ikke specielt dårligt i landet. Mange af de tendenser, der skaber frygt og utryghed i andre lande, er ikke nær så truende i Frankrig: der er mindre ulighed og større omfordeling end $i$ andre OECD-lande, de sociale sikringssystemer er mere udviklede, pensionerne er mere generøse, og sundhedssystemet er blandt de bedste i verden. 
Det grundlæggende problem er, at mange i middelklassen føler, at den sociale kontrakt er blevet brudt. Ingen tror længere på fortællingen om, at man gennem bedre uddannelse vil kunne få et godt job, en bedre indkomst, større velfærd og større muligheder for ens børn.

Hvor kommer utilfredsheden fra? Er det bare en selvopfyldende profeti? Går det dårligt, bare fordi ingen tror på, at det kan gå godt og derfor fremhæver fortiden som et ideal og klamrer sig til gamle privilegier?

Hvis man et øjeblik ser bort fra de psykologiske forklaringer, dækker de samlede tal over store interne forskelle i Frankrig mellem rige og fattige, gamle og unge, centrum og periferi. Livet er først og fremmest blevet besværligere, dyrere og mere prekært på landet. De mennesker, der ikke har ret mange penge og færre muligheder, flytter hen, hvor det er billigst at bo. Der har de så på den anden side brug for længere transport for at komme på arbejde.

Samtidig gennemfører Frankrig de samme strukturreformer som Danmark: færre hospitaler, færre læger, færre politistationer, færre kaserner, færre skoler osv. Da Frankrig er et meget større land, er der mange steder en oplevelse af, at staten helt er forsvundet.

Danmark er til sammenligning kendetegnet ved et meget stærkere civilsamfund og en højere grad af ansvarligt medborgerskab, foreninger og organisationer, der er med til at organisere samfundet og håndtere konkrete opgaver.

Dette civilsamfund er stort set forsvundet i Frankrig. Den katolske kirke, der i århundreder var omdrejningspunktet for især livet uden for de store byer, har ingen betydning længere. Det store gamle kommunistparti, der for venstrefløjen spillede samme rolle som den katolske kirke for højrefløjen, er væk, og det er de andre partier også. Graden af faglig organisation er pinlig lav (kun godt ti pct. af arbejdstagerne er i fagforening), og franskmændene organiserer sig heller ikke i andre foreninger. Der er simpelthen ikke noget fællesskab til at tage over, når staten drosler ned.

Det grundlæggende problem er, at mange i middelklassen føler, at den sociale kontrakt er blevet brudt. Ingen tror længere på fortællingen om, at man gennem bedre uddannelse vil kunne få et godt job, en bedre indkomst, større velfærd og større muligheder for ens børn. Væksten er for beskeden til at give mærkbare forbedringer i købekraften.

Det er ikke længere kun job i industrien, der er truet. Også middelklassens job i servicesektoren er nu i farezonen, efterhånden som den digitale revolutions breder sig til flere og flere sektorer. Samtidig styrker det franske eliteskolesystem indtrykket af, at de bedste uddannelser og de bedste job er forbeholdt dem, der allerede har en plads i solen.

Franskmændene dyrker det individuelle både som ideologi og livsstil, men prisen er en stærk følelse af anonymitet og mistillid. Mistilliden 
er dybt rodfæstet. De fleste har tillid til folk, der er tæt på dem. Det gælder også politikere; borgmestre nyder større grad af tillid end de deputerede, der nyder større grad af tillid end regeringen, der nyder en større grad af tillid end præsidenten. Jo længere væk, jo mindre tillid. Det er fatalt i et system, der er så vertikalt og centraliseret som det franske, et system hvor al beslutningskraft synes samlet hos præsidenten, den instans der er længst væk, og som man derfor stoler mindst på.

Det Frankrig, der gik til valg i 2017, var ikke kun præget af begyndende opløsningstendenser; det balancerede på randen til katastrofen.

\section{Emmanuel Macrons storhed og fald} Det blev Emmanuel Macron, der blev valgt til Frankrigs præsident i maj 2017, og alle åndede lettet op, især på den anden side af Rhinen. Den populistiske bølge var tilsyneladende stoppet. Franskmændene havde besindet sig. Alt syntes klart til en ny begyndelse med en handlekraftigt præsident med et troværdigt reformprogram og en ambitiøs europapolitik ved roret.

Halvandet år efter har Macron med rekordfart mistet sin opbakning. Mekanismen er efterhånden velkendt, for den har gentaget sig ved de tre foregående præsidenter, men man kan alligevel undre sig over, hvad der gik galt denne gang. I modsætning til sine forgængere har Macron loyalt arbejdet på at gennemføre det program, som han blev valgt på. Dér, hvor han har fejlet (det transatlantiske forhold, EU-samarbejdet), har det ikke været hans skyld. Alligevel står han i begyndelsen af 2019 over for den største politiske krise i Frankrig siden maj 68.

Da Macron kom til, stod der ikke sten på sten tilbage af det gamle politiske system. Det betyder imidlertid ikke, at det ikke stadig findes. Hvis man ser på Macrons opbakning, udgør hans kernevælgere omkring 25 pct. af vælgerbefolkningen. Det er den del af befolkningen, der helt overvejende er enig med hans program. Det er vigtigt at notere, at Macron ikke har mistet sin opbakning hos den del af vælgerne. Hans kernevælgere tror stadig på hans projekt.

Macron fik imidlertid også opbakning både fra folk, der tidligere havde stemt socialistisk, og fra folk, der tidligere havde stemt borgerligt. Denne opbakning er af en anden karakter. Disse vælgere stemte på Macron af mangel på bedre, i første omgang fordi deres egen kandidat havde vist sig håbløs, i anden omgang fordi de ville undgå Marine le Pen. Disse vælgere bakker op om dele af Macrons program, men deres støtte er præget af skepsis, og de er ikke loyale hverken over for personen eller projektet.

Der er i udlandet udbredt enighed om, at det var et fornuftigt program, som Macron gik til valg på. Han havde stillet den rigtige diagnose. Han talte om strukturer, der før havde haft en funktion, men som nu var kontraproduktive, fordi de forhindrede mennesker $i$ at udfolde sig. Han ville skabe bevægelse, give bedre adgang til uddannelse og job, sætte individerne fri, øge den sociale mobilitet og forbedre væksten. 
Han pegede på, at de offentlige udgifter i Frankrig var højere end stort set alle andre steder, og at flere skatter og flere overførsler ikke længere kunne være svaret.

De første reformer blev gennemført nogenlunde smertefrit. Arbejdsmarkedsreformen fra efteråret 2017, der på forhånd blev set som en af de største hurdler, blev mødt med de forventede protester, men regeringen havde fået den moderate del af fagbevægelsen med om bord, og den blev gennemført planmæssigt. Det samme gjaldt reformerne af SNCF (de franske statsbaner), af optagelsen til de videregående uddannelser, af terrorlovgivningen, af asylsystemet og en række mindre reformer. Ved hvert tiltag var der protester og strejker i de berørte sektorer, men der kom ikke nogen samlet protest, og modstanden ebbede hurtigt ud.

\section{Social slagside}

Det er dog også klart, at der under den tilsyneladende ro er vokset en frustration frem, der på den ene side har klare årsager, men som på den anden side forekommer fuldstændig irrationel.

For det første er det tydeligt, at Macron i løbet af det første halvandet år ved magten har fremmedgjort den venstreorienterede del af befolkningen. Når han udlægger sin $ø$ konomiske politik, synes mange franskmænd, at han taler med lidt for kraftig tysk accent, for hans arbejdsmarkedsreformer følger samme opskrifter som Gerhard Schröders Agenda 2010: mindre jobsikkerhed, mindre pensioner, mindre understøt- telse. Logikken er den, som vi kender fra styrketræningen: 'no pain, no gain'. Logikken er imidlertid mindre konsistent i politik end i motionscentret, for dem, der ofrer noget, er ikke nødvendigvis de samme som dem, der får gevinst.

De reformer, som Macron har gennemført, har en klar liberal overvægt. De sociale tiltag, der også er annonceret, kommer først om et stykke tid. Macron afskaffede som noget af det første ISF, en særlig skat, der var beregnet på mennesker, der tjener over en mio. euro om året. Samtidig har han ændret boligstøtten, omlagt skat på pensioner og fjernet løntilskudsjob. Macron har en udpræget rationel tilgang til politik, og ud fra et rationelt perspektiv har han ikke gjort noget forkert. Løntilskudsordningen fx fik ikke folk i arbejde, men fastholdt dem i prekære og lavtlønnede job, og det gav også god mening at omlægge ISF fra løn til ejendom.

Politisk og socialt var det klodset, fordi Macron kom til at fremstå som en, der jagtede de svage, mens han plejede de rige. Med ændringen af ISF har venstrefløjen fået et symbol, der kan hives frem ved enhver lejlighed, og der har været en systematisk kampagne for at tegne Macron som 'de riges præsident'.

\section{Europakvaler}

For det andet er Macron kørt fast udenrigspolitisk. Emmanuel Macron indledte sin præsidentkampagne i november 2016 på et tidspunkt, da EU's aktier stod lavere end nogensinde i Frankrig. Det blev betragtet som 


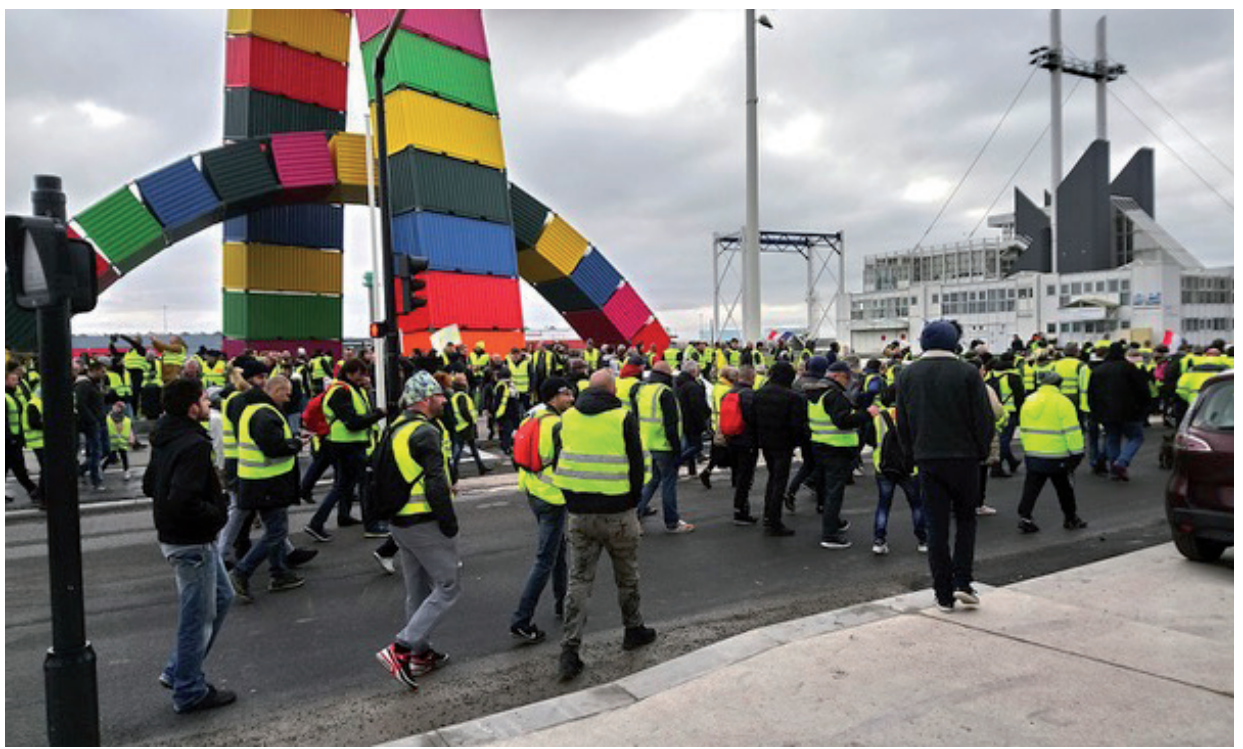

FOTO: Philippe Alès via Wikimedia Commons

'De gule veste' i Le Havre den 12. januar 2019

Hans pointe var ikke, at EU var perfekt eller bare velfungerende; EU var franskmændenes bedste og eneste chance for at spille en rolle i verden.

politisk selvmord at sige noget pænt om EU, men Macron overraskede med et resolut EU-positivt program. Det var tydeligt, at den europæiske dimension var et kernepunkt for ham. På det punkt kom han til at spille hele sin valgkamp på udebane, og han tog alle debatterne ene mand mod de andre. Hans pointe var ikke, at EU var perfekt eller bare velfungerende; EU var franskmændenes bedste og eneste chance for at spille en rolle i verden, uanset om problemet var klimaforandringer, flygtninge, Trump, Rusland, Kina, Mellemøsten Google, Facebook eller Apple.

Valget af Macron i maj 2017 faldt sammen med et markant positivt stemningsskift i Europa i holdningen til EU. Macrons valgsejr havde tilsyneladende stoppet den populistiske bølge. Efter gældskrisen, flygtningekrisen, Brexit og populismens fremmarch overalt, var her en historisk mulighed for at genoplive og forny det fransk-tyske forhold på et tidspunkt, hvor Europa havde allermest brug for det. Allerede i september 2017 stod Frankrig klar i startblokkene. Macrons store Europa-taler i september 2017 (Athen, Sorbonne, Europa-Parlamentet) var nøje afstemt med den tyske kansler Angela Merkel.

Macronisme hviler på den antagelse, at Frankrig har problemer, fordi 
Den dynamiske unge franske præsident, der som $i$ et eventyr vandt den hele republik og den halve omverdens beundring, er tæt på at blive en tragisk helt. det er ude af takt med sine europæiske naboer. Frankrig er med sine store offentlige udgifter og sin høje grad af social beskyttelse en undtagelse. Den implicitte aftale var, at Macron skulle få Frankrig til at ligne de europæiske partnere. Til gengæld skulle Europa overtage nogle af de funktioner (sikkerhed, økonomisk regulering), som nationalstaten havde sværere og sværere ved at udfylde. Macron taler altid varmt om Europa, ikke et hvilket som helst Europa, men det beskyttende Europa. Hans reformer af det franske arbejdsmarked har som mål at gøre Frankrig til en troværdig partner for Tyskland, så den fransk-tysk duo igen vil være i stand til at drive samarbejdet frem.

Der var i september 2017 en fornemmelse af, at det var nu eller aldrig. $\mathrm{Nu}$ skulle det tyske valg bare overstås. Bare halvandet år efter virker forhåbningerne fra 2017 uvirkelige som et folkesagn. I Paris prøver man at opretholde facaden. I Berlin bliver man bare fjerne i blikket, når talen falder på de store ting, der nu skal ske. Sandheden er, at den fransk-tyske duo aldrig kom i gang. Det tyske valg den 24. september 2017 ændrede med ét slag prioriteterne for den tyske regering. Det uklare valgresultat er den mest åbenlyse forklaring på tysk apati i 2017-8.

Det har taget det meste af et år at få etableret en nogenlunde fornuftig rege- ringskoalition. I mellemtiden har Tyskland meldt sig ud af europæisk politik. Den højt besungne tyske stabilitet er blevet til principiel passivitet. Set fra Berlin er sikkerhedspolitik en tilskuersport. Ethvert forsøg på at reformere eurozonen er udskudt på ubestemt tid.

Den dynamiske unge franske præsident, der som i et eventyr vandt den hele republik og den halve omverdens beundring, er tæt på at blive en tragisk helt: Han har lært af fortidens fejltagelser, han ved, hvad der skal gøres, han har viljen til at gøre det, men ingenting kan lade sig gøre, for han er fuldstændig alene, og der er ingen hjælp af hente nogen steder. Mindst af alt hos den tætteste partner, Tyskland.

\section{En dialog mellem døve}

For det tredje har Macron et kommunikationsproblem.

Macron bliver beskyldt for ikke at lytte til folket. Det er ikke rigtigt, men man kan bebrejde ham, at han lytter på samme måde, som forældre lytter til deres børn: som én, der ved, hvad der er bedst for dem. Meget tyder på, at han rent faktisk ved bedst, men det opleves alligevel som et overgreb.

Omvendt er det hævet over enhver tvivl, at en stor del af befolkningen nægter at lytte til ham. Macron er veltalende, men han taler elitens sprog, han bruger ord som 'start-up', optimering, konkurrenceevne. Det sprog, som Macron mestrer til fuldkommenhed, er afskyet hos de franskmænd, der frygter for fremtiden, for de ser det som selve årsagen til deres ulykke. Macron er optimist. Han tror på, at 
reformer virker og vil gøre en forskel, men han er leder af en nation af pessimister, der ikke tror på fremtiden, og som opfatter optimister som enten bedragere eller idioter.

Dertil kommer, at Macron med sit slebne væsen, sin nærmest uforskammede intelligens og sin valgsucces virker som en rød klud på sine modstandere. Han inkarnerer alt det, som mange franskmænd afskyr. Der er opstået et irrationelt had til præsidenten, der nu fungerer som lynafleder for 30 års sammensparede frustrationer. Det kommer fra begge sider af det politiske spektrum, og det næres dagligt af debatten på sociale medier og en stadig strøm af fake news.

Et enkelt eksempel for at illustrere stemningen: Den 22. januar 2019 underskriver Tyskland og Frankrig Aachen-traktaten, en samarbejdsaftale om miljø, uddannelse, kultur og handel for grænseregionen Alsace-Lorraine.

En uge forinden, den 15. januar, lancerer et medlem af Europa-Parlamentet, Bernard Monot (tidligere Front National, nu det suverænistiske Debout la France), på Twitter og Youtube nyheden om, at aftalen har til formål at knægte det franske folk, 'som Macron afskyr', at demontere den franske arbejdsret, at nedlægge de sociale sikringssystemer og forsvaret.

Europaparlamentsmedlemmet konkluderer, at 'Macron som en anden Judas vil udlevere Alsace-Lorraine til en fremmed magt'. Det lyder tilpas skørt til, at ophavsmanden burde kvalificere til en akut mentalundersøgelse. Ikke desto mindre bliver 'nyheden' delt på
Debout la Frances officielle Twitterkonto, og derfra spreder den sig til de forskellige Facebook-fora og Twitterkonti, der har forbindelse til de gule veste, hvor den bliver delt, liket og kommenteret titusindvis af gange og giver anledning til den uundgåelige underskriftsindsamling på change.org.

Fænomenet er fascinerende. Disse bizarre historier spreder sig som en virus båret af russiske bots, af folk, der ikke ved bedre, og af folk, der burde vide bedre, men som er ivrige for dele noget, som bekræfter deres forudfattede meninger.

\section{Halvtreds nuancer af gult}

Macron overtog en dybt fragmenteret og polariseret nation. Hans valgsejr var et lag maling over sprækkerne og revnerne. Disse er nu begyndt at vise sig igen, og de er dybere end nogensinde før.

I efteråret 2018 vedtog den franske regering en omlægning af brændstofafgifterne: man ville som led i den grønne omstilling bringe dieselafgifterne på niveau med benzinafgifterne. Det fik en dame i Bretagne, Jacline Mouraud, til et skrive et indigneret Facebook-opslag, hvor hun opfordrede andre utilfredse til at iføre sig den gule sikkerhedsvest, som alle bilister i Frankrig skal have i deres bil, og blokere de rundkørsler, som det franske vejnet er så rigt udstyret med.

Effekten var fænomenal. Bevægelsen spredte sig udelukkende via Facebook-grupper, men ved den første demonstration den 17 . november var der næsten 300.000 på gaderne. Det var bemærkelsesværdig nok en del af befolkningen, der normalt ikke demon- 
strerer: folk på landet, folk der nærmede sig pensionsalderen, og folk fra middelklassen.

De gule veste har en sag. Frankrig har i årtier favoriseret salget af dieselbiler, der indtil for nylig blev betragtet som mere miljøvenlige end benzinbiler, da de udleder mindre $\mathrm{CO}_{2}$. Indtil for et par år siden var to ud af tre solgte biler $i$ Frankrig en diesel. Nu bliver det meldt ud, at det var en fejl, at dieselbiler udleder skadelige partikler, og at de skal pålægges ekstra miljøudgifter og på længere sigt udfases.

Sagen viser i en nøddeskal Macrons selvskabte problemer. Fra et rationelt synspunkt er forslaget uangribeligt. Diesel forurener, og det er en god idé at udfase det. Når man i et liberalt demokrati vil regulere folks adfærd, er redskabet afgifter, uanset om det drejer sig om tobak eller diesel. Tiltaget var oven i købet annonceret i Macrons program. Der var ikke noget at komme efter.

Politisk og socialt, derimod, er tiltaget håbløst, og det burde nogen have fortalt præsidenten. Brændstofafgifter vender den tunge ende nedad. Transportudgifter fylder forholdsvis mere $i$ et beskedent budget, og de rammer jævne folk, der er tvunget til at bo langt fra deres arbejde, og som er afhængige af deres bil.

Meget af den opbakning, som de gule veste har i den franske befolkning, kan forklares med den naturlige sympati, som man omfatter udsatte mennesker med. Sympatien for de gule veste var i begyndelsen helt oppe på 70 pct. Efter flere måneders ofte ekstremt voldelige demonstrationer med 10 døde og over 3000 sårede deler bevægelsen den franske befolkning, men der er stadig overraskende stor opbakning: en tredjedel støtter de gule veste, en tredjedel har forståelse for de gule veste, en tredjedel er mod de gule veste.

De gule veste er en autentisk græsrodsbevægelse, og det er både dens styrke og den svaghed. Dens styrke fordi den har legitimitet, dens svaghed fordi den ikke kan organisere sig og formulere et projekt.

Selvom de gule veste satte sig på hele sendefladen ved årsskiftet 201819, var der ingen officielle talsmænd. Da premierminister Édouard Philippe inviterede til en rundbordssamtale, var der ingen, der dukkede op, og da 60 gule veste holdt et møde i Marseille den 5. januar for at stifte en reel organisation, var der dobbelt så mange gule veste udenfor, der protesterede mod initiativet og kaldte forsamlingen forrædere og kollaboratører.

Samtidig er det en bevægelse, der konstant muterer. Da regeringen aflyste den planlagte afgiftsforhøjelse, blev den oprindelige protest mod dieselafgiften til en generel kamp for bedre realløn. Igen gav regeringen efter. Den 10. december annoncerede præsident Macron i en tv-tale, at han havde forståelse for de gule vestes krav, han aflyste en planlagt skat på 
pensioner, og han annoncerede et tilskud, der ville forøge indkomsten for folk på mindsteløn med 8.5 pct. Det tog kun en smule luft ud af protesterne, og de gule veste skiftede nu fokus til politiske krav: regeringen skulle gå af, forfatningen skulle ændres, og det skulle indføres direkte demokrati ved hjælp af folkeafstemninger efter borgerinitiativ.

I den henseende er det en ægte populistisk bevægelse. Den har alle de populistiske temaer, folket mod eliten, dyrkelsen af folkeafstemningen, mistroen til demokratiets melleminstanser, først og fremmest presse, partier og fagforeninger, frygten for globaliseringen, hadet til pluralismen og til EU, der repræsenterer alt det, som man gør oprør imod.

Den politiske opposition både til højre og venstre har prøvet at surfe på den gule bølge uden helt at vide, hvad der er under surfbrættet. Bevægelsen rummer alt fra pensionister, der frygter for deres pension, over hypervoldelige autonome fra den yderste venstrefløj til antisemitiske og lige så voldsparate højreekstremister. De gule veste er som sådan et tomt tegn, hvor alle kan se, hvad de gerne selv vil se.

Det yderste venstre, der altid glemmer, at de ikke lever i en diktaturstat, ser de gule veste som endnu en revolution mod undertrykkelse og udbytning i den gode gamle franske tradition. Det er imidlertid hævet over enhver tvivl, at de gule veste har stærk slagside til højre. Der er et konstant og foruroligende fremmedfjendsk, antisemitisk og homofobt tema i bevægelsen. Da de gule veste prøvede at bestemme, hvilke temaer de gerne ville have til folkeafstemning, blev det forslag, der suverænt fik mest støtte, en folkeafstemning om afskaffelse af homoseksuelle ægteskaber.

Hvor efterlader det Macron og Frankrig? Uanset hvordan det går, så er både Macron og Frankrig blevet stærkt svækket. Det er ikke tilfældigt, at de russiske fake news-producenter har gjort, hvad de kunne for at puste til ilden.

Macron har prøvet at genstarte dialogen med den franske befolkning, TV-taler, et brev til alle franskmænd, en stort anlagt national debat om, hvor Frankrig skal hen. Lykkes det ikke, kan man frygte, at Macrons præsidentperiode i praksis er ovre. Hver eneste gang der bliver foreslået noget, der virker truende - regeringen skal i gang med en stor og tiltrængt reform af pensionssystemet $\mathrm{fx}$ - vil folk kunne tage en gul vest på og barrikadere Frankrigs vej ind i det 21. århundrede. 